\title{
PENGARUH OPINI AUDIT TERHADAP HARGA SAHAM DENGAN UKURAN KANTOR AKUNTAN PUBLIK SEBAGAI VARIABEL PEMODERASI
}

\author{
SULIH NUGRAHANI \\ UniversitasPamulang \\ ohhanni28@gmail.com \\ ENDANG RUHIYAT \\ UniversitasPamulang \\ holienroe@yahoo.co.id
}

\begin{abstract}
The purpose of this research is to prove empirically the influence of audit opinions on stock prices. In addition, this research also examined the moderation role of the size of the Public Accounting Firm on the relationship of audit opinion with stock prices. This research uses profitability and liquidity control variables. Companies studied are manufacturing companies listed on the Indonesia Stock Exchange 2012-2015.Sampling method used is purposive sampling method and obtained 63 companies that become the object of research. The data used are financial reports and independent auditor's reports published through www.idx.co.id and the list of stock prices through www.sahamok.com. The research hypothesis was tested using multiple linear regression analysis technique with moderated regression analysis (MRA).Based on the test results show that the audit opinion does not significantly affect the stock price. This study also shows that the size of Public Accounting Firm has no moderating on the relationship of audit opinion with stock price.
\end{abstract}

Keywords: stock price, audit opinion, size of Public Accounting Firm

\section{PENDAHULUAN}

Purbawati (2016), menunjukkan bahwa opini audit berpengaruh terhadap perubahan harga saham.Harga saham merupakan cermin dari kondisi perusahaan, perusahaan dengan prospek yang bagus akan memiliki harga saham yang tinggi (Ferdianto, 2014). Oleh karena itu investor sangat memperhatikan harga saham perusahaan yang akan dibelinya. Tujuan utama para investor adalah mendapatkan keuntungandari investasi tersebut. Menurut Meythi, dkk (2011) keuntungan yangdiperoleh investor dari penanaman modal saham ini dapat berasal dari laba perusahaan yang dibagikan atau dividen, dan kenaikan atau penurunan harga saham.Peningkatan maupun penurunan harga saham dipengaruhi banyak faktor, ada faktor internal dan ada pula faktor eksternal.Faktoreksternal yang mempengaruhi harga pasar seperti kondisi perekonomian, kebijakanpemerintah, inflasi, kondisi politik, dan lain-lain.Faktor internal yang mempengaruhiharga saham seperti keputusan manajemen, kebijakan internal manajemen dankinerja perusahaan.Perusahaan tidak dapat mengendalikan faktor eksternal karenafaktor tersebut terjadi diluar perusahaan.Namun perusahaan dapat mengendalikanfaktor internal agar harga saham mereka tidak turun. Salah satu cara mengendalikan faktor internal adalahmelalui kinerja perusahaan.

Kinerja perusahaan yang sudah go public dapat dilihat dari laporan keuangan yang dipublikasikan untuk umum. Laporan keuangan sangat membantu para investor untuk 
mengetahui kondisi perusahaan, terutama jika laporan keuangan tersebut sudah diaudit. Disinilah peran audit sangatlah penting, laporan yang dikeluarkan audit independen salah satunya menghasilkan suatu pernyataan (opini) mengenai kewajaran laporan keuangan.

Berkaitan dengan opini auditor, bahwa opini audit merupakan kesimpulan auditor terhadap proses audit yang telah dilaksanakan dan pendapat mengenai kewajaran isi laporan keuangan perusahaan (Pardosi, 2012). Suatu informasi akan memiliki makna bagi investor jika informasi tersebut menyebabkan para investor melakukan transaksi di pasar modal, semua transaksi ini tercermin dalam perubahan harga saham (Laksitafresti, 2012). Opini auditor sebagai informasi yang penting, membuat opini auditor akan berpengaruh terhadap harga saham di pasar modal. Opini auditor merupakan sumber informasi bagi pihak di luar perusahaan sebagai pedoman untuk pengambilan keputusan.Bagi calon investor, opini auditor atas laporan keuangan menjadi salah satu pertimbangan penting dalam mengambil keputusan berinvestasi. Penelitian mengenai pengaruh opini audit terhadap harga saham, diperkuat dengan penelitian Sidabutar (2014), hasil dari penelitiannya menunjukkan bahwa opini audit berpengaruh positif dan parsial terhadap harga saham. Hasil penelitian Lin dan Wu (2009) membuktikan adanya pengaruh yang signifikan negatif antara pengumuman opini audit dengan harga saham.

Opini audit dalam laporan keuangan, dilakukan oleh auditor kantor akuntan publik (KAP) yang berbeda-beda. Kantor akuntan publik yang berkualitas dianggap telah memiliki keahlian yang tinggi untuk mendeteksi salah saji material yang terdapat dalam laporan keuangan (Almuntaha, dkk, 2016).Ukuran KAP berpengaruh terhadap kualitas opini yang dinyatakan auditor.Ukuran KAP mencerminkan kualitas opini audit yang dapat mempengaruhi investor dalam investasi saham.Penelitian yang dilakukan oleh Pardosi (2012), menyatakan bahwa ukuran KAP secara parsial berpengaruh positif terhadap harga saham.Ukuran KAP memiliki hubungan yang kuat terhadap harga saham, karena KAP big four secara umum dapat melakukan audit lebih professional dibandingkan KAP non big four.Harga saham juga terpengaruh tingkat laba perusahaan.Karena apabila laba suatu perusahaan meningkat, maka harga saham perusahaan tersebut juga akan meningkat atau dengan kata lain, ROA mempengaruhi harga saham. Penelitian yang dilakukan oleh Kabajeh, et.al (2012) menunjukkan bahwa secara parsial ROA berpengaruh terhadap harga saham. Fahlevi (2013) menyatakan bahwa ROA berpengaruh dalam memprediksi harga saham.Wiasta (2010) menunjukkan bahwa ROA berpengaruh signifikan terhadap harga saham.Selain itu, tingkat likuiditas perusahaan dapat mempengaruhi harga saham.Fahlevi (2013), menunjukkan bahwa current ratio berpengaruh secara parsial untuk memprediksi harga saham. Penelitian Setiyawan (2014), hasil penelitiannya menunjukkan bahwa current ratio berpengaruh positif dan signifikan terhadap harga saham. Penelitian yang dilakukan Sarwono (2016), lebih membuktikan bahwa secara parsial likuiditas berpengaruh positif dan signifikan terhadap harga saham.

Penelitian ini bermaksud mengembangkan hasil penelitian Lin \& Wu (2009), Pardosi (2012), Fahlevi (2013), Setiyawan (2014) dan Sarwono (2016).Objek penelitian menggunakan data sekunder yang diperoleh dari laporan keuangan industri manufaktur di Bursa Efek Indonesia (BEI).Alasan peneliti menggunakan industri tersebut karena populasi pada sektor manufaktur lebih besar, sehingga dapat digunakan untuk pengambilan sampel yang mewakili industri dari sektor manufaktur yang terdaftar di Bursa Efek Indonesia. Tujuan peneliti melakukan penelitian ini untuk lebih membuktikan secara empiris pengaruh opini auditterhadap harga saham dengan ukuran kantor akuntan publik sebagai variabel moderatingpada perusahaan sektor manufaktur yang terdaftar di BEI tahun 20132015.Penelitian ini bertujuan untuk menguji dan memperoleh bukti empirismengenai 
pengaruh opini audit terhadap harga saham dan efek moderasi dari variabel ukuran kantor akuntan publik terhadap hubungan antara opini audit dengan harga saham.Hasil penelitian ini diharapkan dapat memberikan manfaat bagi pihak-pihak berikut: Pertama, diharapkan hasil penelitian ini dapat memberikan petunjuk bagi investor mengenai sinyal yang disampaikan oleh perusahaan melalui harga saham, opini audit dan ukuran kantor KAP untuk mengetahui prospek perusahaan di masa yang akan datang. Kedua, hasil penelitian ini dapat digunakan oleh perusahaan sebagai bahan pertimbangan dalam menentukan auditor yang mengaudit laporan keuangan perusahaan dan ukuran KAP yang ideal agar direspon positif oleh investor.Ketiga, hasil penelitian ini diharapkan dapat menambah pengetahuan, gambaran dan bukti empiris mengenai pengaruh opini audit dan ukuran KAP terhadap harga saham.

\section{TINJAUAN PUSTAKA DAN PENGEMBANGAN HIPOTESIS Teori Signal}

Teori signal menjelaskan tentang bagaimana seharusnya sebuah perusahaan memberikan signal kepada pengguna laporan keuangan mengenai kondisi perusahaan yang sebenarnya, karena tidak semua informasi tentang perusahaan diketahui oleh pihak luar, terutama investor (Prasetyo dan Rini, 2014). Signal dapat berupa promosi atau informasi lain yang menyatakan bahwa perusahaan tersebut lebih baik dari perusahaan lain.Konsekuensi logis dari teori signal adalah ada banyak insentif untuk seluruh manajer untuk memberikan signal harapan keuntungan masa depan karena jika investor mempercayai signal tersebut, harga saham akan naik dan pemegang saham akan diuntungkan.Jadi teori signal ini menunjukkan bahwa harga saham dapat memberikan sinyal untuk para investor dalam hal pengambilan keputusan berinvestasi di perusahaan yang bersangkutan.

\section{Teori Legitimasi}

Menurut Deegan (2002) dalam Mardiyatnolo, dkk (2016), teori legitimasi menyatakan bahwa suatu organisasi hanya bisa bertahan jika masyarakat dimana dia berada merasa bahwa organisasi beroperasi berdasarkan sistem nilai yang sepadan dengan sistem nilai yang dimiliki oleh masyarakat.Teori legitimasi menempatkan persepsi dan pengakuan publik sebagai dorongan utama dalam melakukan pengungkapan suatu informasi di dalam laporan keuangan (Ariningtika, 2013). Oleh karena itu teori legitimasi menjelaskan bahwa opini audit yang terdapat dalam laporan tahunan(annual report), merupakan suatu informasi yang penting untuk masyarakat, baik investor maupun pengguna laporan keuangan lainnya. Terkait dengan kantor akuntan publik (KAP), teori legitimasi memberi dasar bahwa KAP harus memiliki dasar norma dan etika yang selaras dengan kepercayaan masyarakat dalam menjalankan pekerjaannya. KAP big four menunjukkan bahwa perusahaan memiliki legitimasi yang lebih besar dibandingkan dengan non big four karena penerimaan dan kepercayaan masyarakat lebih besar.

\section{Harga Saham}

Harga saham merupakan nilai suatu saham yang mencerminkan kekayaan perusahaan yang mengeluarkan saham tersebut.Perubahan harga saham dipengaruhi oleh kekuatan permintaan dan penawaran yang terjadi di pasar sekunder. Semakin banyak investor yang ingin membeli atau menyimpan suatu saham, maka harganya akan semakin naik, dan sebaliknya jika semakin banyak investor yang menjual atau melepaskan maka akan berdampak pada turunnya harga saham (Anisma, 2012).Harga saham dapat diukur dari nilai harga saham saat penutupan (closing price) (Pardosi, 2012).Harga saham juga bisa diukur dengan nilai harga saham per bulan dari sampel penelitian (Amperaningrum dan Agung, 
2011).Selain itu harga saham juga dapat diukur menggunakan harga saham rata-rata per tahun (Sutanto, 2007).Pengukuran terhadap adanya perubahan harga saham dilakukan dengan cara menghitung average abnormal return (Susila, 2015). Berdasarkan beberapa pendapat diatas, dapat disimpulkan harga saham adalah nilai yang menunjukkan perubahan besar kecilnya angka saham dan digunakan sebagai acuan untuk investor dalam pertimbangan berinvestasi.

\section{Opini Audit}

Opini audit adalah kesimpulan auditor terhadap proses audit yang telah dilaksanakan dan pendapat mengenai kewajaran laporan keuangan perusahaan (Laksitafresti, 2012).Opini auditor merupakan sumber informasi bagi pihak di luar perusahaan sebagai pedoman untuk pengambilan keputusan.Bagi calon investor, opini auditor atas laporan keuangan menjadi salah satu pertimbangan penting dalam mengambil keputusan berinvestasi.Teori legitimasi menempatkan persepsi dan pengakuan publik sebagai dorongan utama dalam melakukan pengungkapan suatu informasi di dalam laporan keuangan (Ariningtika, 2013). Oleh karena itu teori legitimasi menjelaskan bahwa opini audit yang terdapat dalam laporan tahunan (annual report), merupakan suatu informasi yang penting untuk masyarakat, baik investor maupun pengguna laporan keuangan lainnya. Perusahaan menyajikan informasi yang lebih lengkap dan rinci, perusahaan dapat memberikan informasi yang akurat dan bersifat publik yang di laporkan di BEI.Dengan begitu perusahaan berusaha untuk mendapatkan pengakuan masyarakat bahwa perusahaan telah beroperasi sesuai dan selaras dengan harapan masyarakat maupun lingkungan sosial.

\section{Ukuran Kantor Akuntan Publik (KAP)}

Kantor akuntan publik yang berkualitas dianggap telah memiliki keahlian yang tinggi untuk mendeteksi salah saji material yang terdapat dalam laporan keuangan (Almuntaha, dkk, 2016).Ukuran KAP adalah besar kecilnya perusahaan audit (Chrisnoventie, 2012). Ukuran KAP dibedakan menjadi dua KAP yaitu KAP besar (big four accounting firms) dan KAP kecil (non big four accounting firms). KAP besar (big four accounting firms) dipersepsikan akan melakukan audit dengan lebih berkualitas dibandingkan dengan KAP kecil (non big four accounting firms). Hal tersebut karena KAP besar memiliki lebih banyak sumber daya dan lebih banyak klien sehingga mereka tidak tergantung pada satu atau beberapa klien saja, selain itu mereka reputasinya yang telah dianggap baik oleh masyarakat menyebabkan KAP besar tersebut melakukan audit serta menyatakan opini dengan lebih hati-hati (Putri, 2012).Ukuran kantor akuntan publik diukur dengan variabel dummy, dimana nilai 1 untuk KAP big four dan nilai 0 untuk KAP non big four (Pardosi, 2012).

\section{Profitabilitas}

Rasio profitabilitas menghubungkan laba dengan besaran tertentu yaitu penjualan maupun modal atau aktiva yang digunakan untuk menghasilkan laba (Ferdianto, 2014). Menurut Ratri (2015), rasio profitabilitas atau dapat disebut juga dengan rasio rentabilitas adalah rasio yang digunakan untuk mengukur pengaruh likuiditas, hutang, manajemen aset terhadap hasil operasi suatu perusahaan. Profitabilitas diukur menggunakan return on assets (ROA), profit margin, return on equity (ROE), dan earning per share (EPS). Return on equity merupakan rasio yang mengukur kemampuan perusahaan menghasilkan laba berdasarkan modal saham tertentu (Hanafi dan Halim, 2012:82). Rasio ini merupakan ukuran profitabilitas dari sudut pandang pemegang saham.Earning per share atau laba per saham digunakan untuk menganalisis kemampuan perusahaan mencetak laba berdasarkan saham 
yang dimiliki (Hanafi dan Halim, 2012:184).Laba per saham dapat mengukur perolehan tiap unit investasi pada laba bersih perusahaan dalam periode tertentu.

\section{Likuiditas}

Menurut Hanafi dan Halim (2012:75), rasio likuiditas mengukur kemampuan likuiditas jangka pendek perusahaan dengan melihat aktiva lancar perusahaan relatif terhadap utang lancarnya.Untuk mengukur kemampuan ini, digunakan current ratio dan quick ratio. Tinggi rendahnya current ratio suatu perusahaan mencerminkan kemampuan suatu perusahaan dalam membayar kewajibannya tersebut.Current ratio yang terlalu tinggi menunjukkan adanya kelebihan uang kas atau aktiva lancar lainnya dibandingkan dengan yang dibutuhkan sekarang.Jadi, current ratio dapat menunjukkan sejauh mana aktiva lancar menjamin pembayaran dari kewajiban lancarnya, sehingga hal tersebut dapat mempengaruhi minat para investor untuk menanamkan modalnya pada perusahaan. Akibatnya, Harga Saham perusahaan tersebut juga akan naik (Wicaksono, 2013).

\section{Kerangka Konseptual}

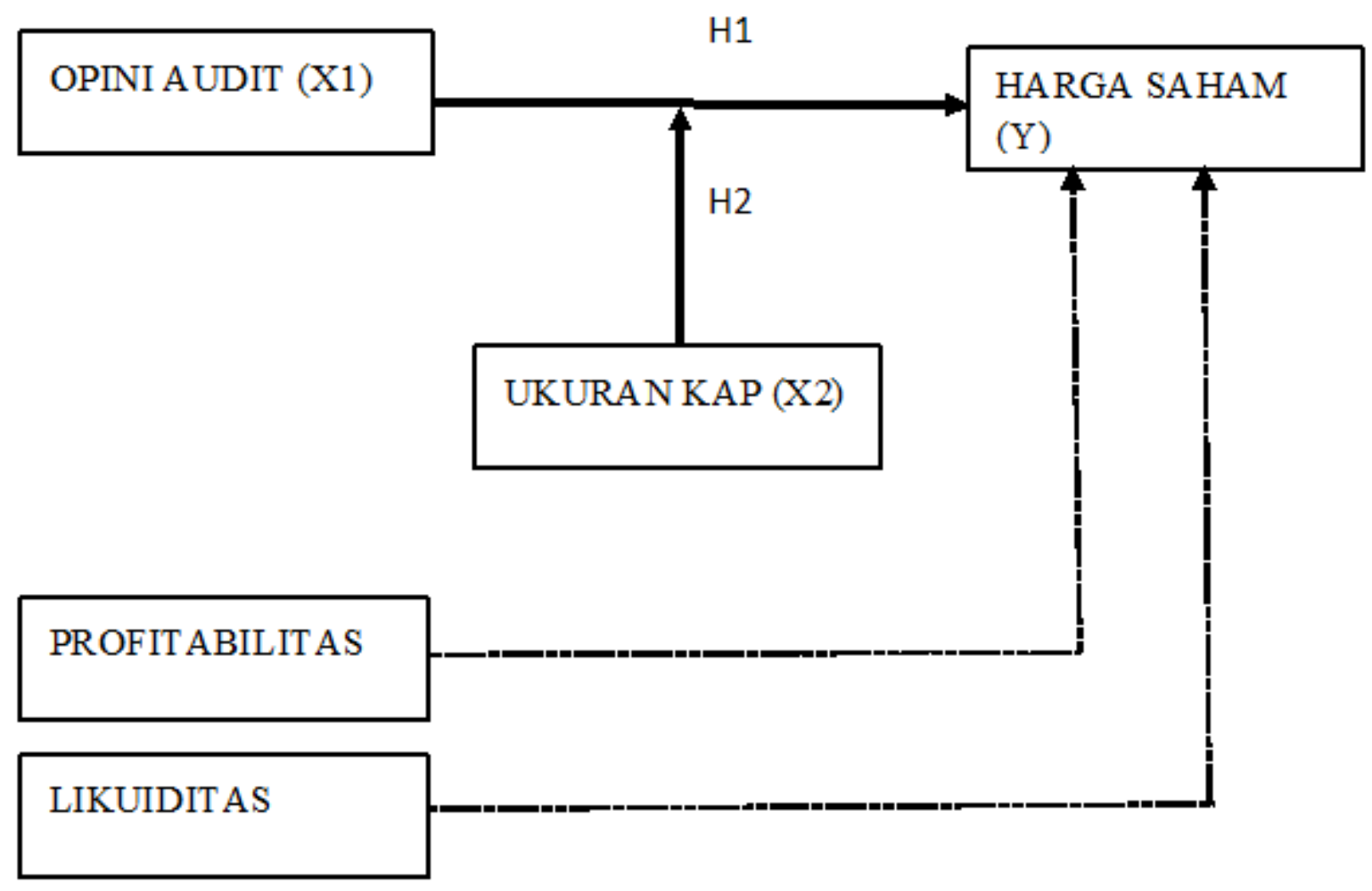

Gambar 2.1

Kerangka Konseptual

\section{Pengembangan Hipotesis}

Lin and $\mathrm{Wu}$ (2009) membuktikan adanya pengaruh yang signifikan negatif antara pengumuman opini audit dengan harga saham. Hasil penelitianFadillah (2015) menunjukkan bahwa opini audit wajar tanpa pengecualian dengan bahasa penjelas mengenai inkonsistensi penerapan PABU berpengaruh signifikan terhadap harga saham.Penelitian Kipkosgei (2010), menunjukkan adanya hubungan signifikan negatif antara opini audit terhadap harga saham. 
Purbawati (2016), menunjukkan bahwa opini audit berpengaruh terhadap perubahan harga saham. Hal ini diperkuat dalam penelitian yang dilakukan oleh Sidabutar (2014), menunjukkan bahwa secara parsial opini audit berpengaruh positif dan signifikan terhadap harga saham.Atas dasar itu, hipotesis yang dapat diajukan dalam penelitian ini adalah :H1 : Diduga Opini audit berpengaruh terhadap harga saham.

Penelitian yang dilakukan oleh Pardosi (2012), menyatakan bahwa ukuran KAP secara parsial berpengaruh positif terhadap harga saham.Ukuran KAP memiliki hubungan yang kuat terhadap harga saham, karena KAP big four secara umum dapat melakukan audit lebih professional dibandingkan KAP non big four. Penelitian Sidabutar (2014), membuktikan bahwa ukuran KAP berpengaruh secara parsial terhadap harga saham. Dengan demikian, semakin besar ukuran KAP, kualitas hasil opini audit pun semakin baik.Berdasarkan penjelasan di atas, maka hipotesis yang dapat diajukan dalam penelitian ini adalah :H2 : Diduga Ukuran KAP dapat memperkuat pengaruh opini audit terhadap harga saham.

\section{METODE PENELITIAN}

\section{Pemilihan Sampel dan Pengumpulan Data}

Populasi yang menjadi objek dalam penelitian ini adalah perusahaan manufaktur yang terdaftar di Bursa Efek Indonesia (BEI) tahun 2013-2015 sebanyak 138 perusahaan.Sampel dipilih dengan menggunakan teknik purposive sampling. Kriteria penentuan sampel dalam penelitian ini adalah: Perusahaan manufaktur yang listed secara berturut-turut di Bursa Efek Indonesia (BEI) periode 2013-2015, perusahaan menerbitkan laporan keuangan per 31 Desember dalam satuan mata uang rupiah, perusahaan yang dalam annual report-nya tidak mengalami kerugian selama periode 2013-2015, adanya laporan independen auditor, harga saham penutupan (closing price) perusahaan terdaftar dalam website saham (www.sahamok.com).

Data yang digunakan dalam penelitian ini adalah data sekunder. Data tersebut diperoleh dengan menggunakan metode dokumentasi, dimana dilakukan dengan cara menggumpulkan laporan tahunan (annual report) beserta laporan keuangan industri manufaktur yang telah diaudit melalui website Bursa Efek Indonesia (BEI) yaitu www.idx.co.id dan data harga saham dikumpulkan melalui www.sahamok.com.

\section{Variabel dan Pengukuran Harga Saham}

Harga saham merupakan indeks prestasi perusahaan, yaitu seberapa jauh manajemen telah berhasil mengelola perusahaan atas nama pemegang saham (Ferdianto, 2014). Data harga saham pada penelitian ini diukur dengan satuan rupiah.Harga saham diukur dari nilai harga saham saat penutupan (closing price) (Pardosi, 2012).

\section{Opini Auditor}

Opini auditor adalah kesimpulan auditor terhadap proses audit yang telah dilaksanakan dan pendapat mengenai kewajaran laporan keuangan perusahaan (Susila, 2015). Pengukuran variabel opini audit ini menggunakan variabel dummy.Jika perusahaan klien menerima opini wajar tanpa pengecualian (unqualified opinion) maka diberikan nilai 1, sedangkan jika perusahaan menerima opini selain wajar tanpa pengecualian (qualified opinion) diberikan nilai 0 (Purbawati, 2016).

\section{Ukuran Kantor Akuntan Publik}

Kantor akuntan publik adalah suatu bentuk organisasi akuntan publik yang memperoleh izin sesuai dengan peraturan perundang-undangan yang berusaha di bidang 
pemberian jasa professional dalam praktik akuntan publik (Agoes, 2016:44). Ukuran KAP adalah besar kecilnya perusahaan audit (Chrisnoventie, 2012). Dalam penelitian ini ukuran KAP diukur menggunakan variabel dummy.Jika laporan keuangan di audit oleh KAP big four maka diberikan nilai 1 sedangkan untuk KAP non big four diberikan nilai nol (Pardosi, 2012).

\section{Profitabilitas}

Rasio profitabilitas adalah rasio untuk menilai kemampuan perusahaan dalam meningkatkan laba (Fahlevi, 2013).Rasio profitabilitas adalah rasio keuangan yang digunakan untuk mengukur kemampuan perusahaan memperoleh laba dalam hubungannya dengan penjualan, total aktiva, investasi, maupun modal sendiri. Profitabilitas diukur menggunakan Return on Assets(Kabajeh, et.al, 2012).ROA mengukur tingkat laba terhadap aset yang digunakan dalam menghasilkan laba (Prihadi, 2011:152). Rasio ini diukur dengan rumus:

\section{Likuiditas}

$$
\text { ROA }=\frac{\text { Laba Bersih }}{\text { Total Aktiva }}
$$

Menurut Prastowo (2014:153), likuiditas menggambarkan kemampuan perusahaan untuk membayar kewajiban jangka pendek (short-term debt) pada saat jatuh tempo. Likuiditas diukur menggunakan current ratio (Setiyawan, 2014).Current ratio merupakan elemen-elemen yang digunakan dalam perhitungan modal kerja dapat dinyatakan dalam rasio, yang membandingkan antara total aktiva lancar dan utang lancar (Prastowo, 2014:84). Rasio ini diukur dengan rumus:

Current Ratio $=\frac{\text { Aktiva Lancar }}{\text { Utang Lancar }}$

\section{Metode Analisis}

Model pengujian hipotesis menggunakan metode analisis regresi linear berganda.Dalam penelitian ini analisis yang digunakan yaitu Moderated Regression Analysis $(M R A)$.Persamaan regresi yang digunakan untuk meguji hipotesis, sebagai berikut : $\mathrm{HS}=\alpha+\beta 1 \mathrm{OA}+\beta 2 \mathrm{KAP}+\beta 3 \mathrm{OA} \cdot \mathrm{KAP}+\beta 4 \mathrm{PROF}+\beta 5 \mathrm{LIKD}+\mathrm{e}$

Keterangan :

\begin{tabular}{|c|c|}
\hline HS & $=$ Harga Saham \\
\hline$\alpha$ & $=$ Konstanta \\
\hline$\beta$ & $=$ Koefisien regresi \\
\hline $\mathrm{OA}$ & $=$ Opini Audit \\
\hline KAP & $=$ Ukuran KAP \\
\hline PROF & $=$ Profitabilitas \\
\hline LIKD & $=$ Likuiditas \\
\hline & $=$ Error \\
\hline
\end{tabular}

HASIL PENELITIAN DAN PEMBAHASAN Deskripsi Sampel Penelitian

\section{Tabel}

\section{Proses Seleksi Sampel}

\begin{tabular}{clc}
\hline No & \multicolumn{1}{c}{ Kriteria } & Jumlah \\
\hline 1 & $\begin{array}{l}\text { Perusahaan manufaktur yang terdaftar (listed) secara berturut- } \\
\text { turut di Bursa Efek Indonesia (BEI) periode 2013-2015. }\end{array}$ & 138 \\
2 & $\begin{array}{l}\text { Perusahaan menerbitkan laporan keuangan per 31 Desember } \\
\text { dalam satuan mata uang rupiah. }\end{array}$ & (23)
\end{tabular}


3 Perusahaan memiliki laporan tahunan (annual report) periode 2013-2015.

4 Adanya laporan independen auditor.

5 Harga saham penutupan (closing price) perusahaan terdaftar dalam website saham (www.sahamok.com).

6 Perusahaan yang tidak mengalami kerugian dalam periode 2013-2015.

Jumlah Sampel Perusahaan Jumlah Tahun Penelitian Total Sampel Selama Periode Penelitian $(63 * 3)$

Sumber : Data Sekunder diolah penulis

Dari hasil pembahasan sampel maka dapat diperoleh sampel penelitian yaitu 63 perusahaan dan dengan data 3 (tiga) tahun maka jumlah sampel data penelitian sebanyak 189 data tahun penelitian.

\section{Analisis Statistik Deskriptif}

\section{Tabel}

Hasil Uji Statistik Deskriptif Setelah Transformasi

\begin{tabular}{|c|c|c|c|c|c|c|}
\hline & $\begin{array}{c}\text { LN_HAR } \\
\text { GA_SAH } \\
\text { AM }\end{array}$ & $\begin{array}{l}\text { Opini } \\
\text { Audit }\end{array}$ & $\begin{array}{c}\text { Ukuran } \\
\text { KAP }\end{array}$ & $\begin{array}{c}\text { Profitabilit } \\
\text { as }\end{array}$ & $\begin{array}{c}\text { Likuidita } \\
\text { S }\end{array}$ & $\begin{array}{c}\text { Valid N } \\
\text { (listwis } \\
\text { e) }\end{array}$ \\
\hline$\overline{\mathrm{N}}$ & 189 & 189 & 189 & 189 & 189 & 189 \\
\hline Minimum & 3.91 & 0 & 0 & .0004 & .4030 & \\
\hline Maximum & 14.00 & 1 & 1 & .5000 & 13.8713 & \\
\hline Mean & 7.2602 & .67 & .43 & .094399 & 2.833002 & \\
\hline Std. & 190163 & 471 & 496 & 0926379 & 2.560444 & \\
\hline Deviation & 1.90103 & .4/1 & . 490 & $.09203 / 9$ & 3 & \\
\hline
\end{tabular}

Sumber : Data diolah menggunakan SPSS 22

Berdasarkan table diatasharga saham memiliki nilai minimum 3.91, maximum 14.00, rata-rata 7.2602 dengan standar deviasi 1.90163. Opini audit memiliki nilai minimum 0, maximum 1, rata-rata 0.67 dan standar deviasi 0.471 . Ukuran KAP memiliki nilai minimum 0 , maximum 1, rata-rata 0.43 dan standar deviasi 0.496 .Profitabilitas memiliki nilai minimum 0.0004, maximum 0.5, rata-rata 0.094399 dan standar deviasi 0.0926379.Likuiditas memiliki nilai minimum 0.4030 , maximum 13.8713 , rata-rata 2.833002 dan standar deviasi sebesar 2.5604443.Jadi disimpulkan bahwa setelah dilakukan transformasi variabel dependen (harga saham), nilai minimum, maximum, rata-rata, dan standar deviasi menunjukkan data-data penelitian yang terdistribusi normal.

Tabel

Hasil Uji Skewness dan Kurtosis Setelah Transformasi

\begin{tabular}{lccccr}
\hline & $\mathrm{N}$ & \multicolumn{2}{c}{ Skewness } & \multicolumn{2}{c}{ Kurtosis } \\
& Statistic & Statistic & Std. Error & Statistic & Std. Error \\
\hline Unstandardized & 189 & .300 & .177 & -.008 & .352 \\
Residual & 189 & & & & \\
Valid N (listwise) & 189 & & & &
\end{tabular}

Sumber : Data diolah menggunakan SPSS 22 
Dari nilai skewness dan kurtosis dapat dihitung nilai Zskewness dan Zkurtosis sebagai berikut :

$$
\begin{aligned}
& Z \text { skewness }=\frac{0.300}{\sqrt{6 / 189}}=1.684 \\
& Z \text { kurtosis }=\frac{-0.008}{\sqrt{24 / 189}}=-0.022
\end{aligned}
$$

Hasil perhitungan menunjukkan bahwa Zskewness dan Zkurtosis lebih kecil dari 1.96 pada signifikan 0.05, berarti Zhitung $<$ Ztabel $(1.684<1.96$ dan $-0.008<1.96)$ maka data residual terdistribusi normal.

Tabel Hasil Uji Kolmogorov-Smirnov Setelah Transformasi

\begin{tabular}{lr}
\hline & $\begin{array}{c}\text { Unstandardized } \\
\text { Residual }\end{array}$ \\
\hline $\mathrm{N}$ & 189 \\
Asymp. Sig. (2-tailed) & $.200^{\text {c,d }}$ \\
\hline
\end{tabular}

Sumber : Data diolah dengan SPSS 22

Berdasarkan pengujian di atas, jumlah residual adalah 189 sampel, nilai signifikan pada 0.200 sehingga dapat disimpulkan bahwa data terdistribusi normal dimana $0.200>0.05$. Dengan demikian secara keseluruhan bahwa nilai observasi telah terdistribusi normal.

\section{Diskusi Hasil dan Pembahasan}

\section{Hasil Uji Statistik t

\begin{tabular}{|c|c|c|c|c|c|c|c|c|c|c|}
\hline \multirow[b]{2}{*}{ Model } & $\begin{array}{l}\text { Unstan } \\
\text { Coeffi }\end{array}$ & $\begin{array}{l}\text { dardiz } \\
\text { cients } \\
\text { Std. }\end{array}$ & $\begin{array}{l}\text { Standardize } \\
\mathrm{d} \\
\text { Coefficient } \\
\mathrm{s}\end{array}$ & \multirow[b]{2}{*}{$\mathrm{t}$} & \multirow[b]{2}{*}{ Sig. } & \multicolumn{3}{|c|}{$\begin{array}{l}\text { Correlations } \\
\text { Zero- Partia }\end{array}$} & \multicolumn{2}{|c|}{$\begin{array}{l}\text { Collinearity } \\
\text { Statistics } \\
\text { Toleranc }\end{array}$} \\
\hline & $\mathrm{B}$ & Error & Beta & & & order & 1 & Part & $\mathrm{e}$ & VIF \\
\hline (Constant) & 5.720 & .233 & & $\begin{array}{r}24.50 \\
4\end{array}$ & .000 & & & & & \\
\hline $\begin{array}{l}\text { Opini } \\
\text { Audit }\end{array}$ & .182 & .262 & .045 & .697 & .487 & .005 & .051 & .035 & .609 & 1.641 \\
\hline $\begin{array}{l}\text { Ukuran } \\
\text { KAP }\end{array}$ & 1.282 & .392 & .335 & 3.268 & .001 & .519 & .235 & .165 & .244 & 4.101 \\
\hline $\mathrm{OA} * \mathrm{KAP}$ & -.289 & .437 & -.072 & -.662 & .509 & .337 & -.049 & $\begin{array}{r}-.03 \\
3\end{array}$ & .219 & 4.576 \\
\hline $\begin{array}{l}\text { Profitabilit } \\
\text { as }\end{array}$ & 11.651 & 1.200 & .568 & 9.709 & .000 & .672 & .583 & .491 & .748 & 1.337 \\
\hline Likuiditas & -.048 & .039 & -.065 & 1.234 & .219 & -.015 & -.091 & $\begin{array}{r}-.06 \\
2 \\
\end{array}$ & .915 & 1.093 \\
\hline
\end{tabular} \\ Coefficients $^{\mathbf{a}}$}


a. Dependent Variable: LN_HARGA_SAHAM

\section{Pengaruh Opini Audit terhadap Harga Saham}

Berdasarkan uji koefisien determinasi untuk melihat nilai adjusted $\mathrm{R}^{2}$ dalam mengukur seberapa jauh variabel dependen dapat dijelaskan oleh variabel-variabel independen. Nilai adjusted $\mathrm{R}^{2}$ sebesar 0.519 , berarti $51.9 \%$ harga saham dapat dijelaskan oleh opini audit. Sedangkan sisanya $48.1 \%$ dijelaskan oleh variabel lain diluar model penelitian ini.Berdasarkan uji t bahwa H1, diketahui nilai t hitung 0.697, sedangkan $t$ tabel 1.9726 dan diperoleh nilai signifikan 0.487 dengan tingkat signifikansi 0.05 . Dengan demikian dapat disimpulkan, $\mathrm{t}$ hitung $<\mathrm{t}$ tabel atau $0.697<1.9726$ dan nilai signifikansi $0.487>0.05$ sehingga $\mathrm{H} 1$ ditolak yang berarti opini audit tidak berpengaruh signifikan terhadap harga saham.

Hasil penelitian ini tidak sejalan dengan penelitian yang dilakukan oleh Lin and $\mathrm{Wu}$ (2009) dan Kipkosgei (2010) yang membuktikan adanya pengaruh signifikan negatif antara opini audit dengan harga saham. Penelitian ini juga tidak sejalan dengan penelitian Fadillah (2015), Purbawati (2016), dan Sidabutar (2014) membuktikan bahwa opini audit berpengaruh signifikan positif terhadap harga saham.Jadi penelitian ini menunjukkan bahwa opini audit tidak berpengaruh signifikan positif maupun negatif terhadap harga saham. Keadaan tersebut menunjukkan bahwa opini audit tidak memiliki kandungan informasi, karena tidak memberikan pengaruh terhadap harga saham. Hal tersebut bisa terjadi karena investor tidak menjadikan opini audit sebagai sinyal atau dasar pengambilan keputusan untuk menanamkan saham perusahaan, sehingga tidak terjadi perubahan harga saham yang signifikan.

\section{Pengaruh Ukuran Kantor Akuntan Publik terhadap Hubungan Opini Audit dengan Harga Saham}

Nilai adjusted $\mathrm{R}^{2}$ sebesar 0.519 , berarti $51.9 \%$ harga saham dapat dijelaskan oleh ukuran KAP. Sedangkan sisanya 48.1\% dijelaskan oleh variabel lain diluar model penelitian ini. Berdasarkan hasil pengujian MRA dimana variabel moderating dirumuskan dengan perkalian opini audit dengan ukuran KAP (OA*KAP) diketahui t hitung $=-0.662$ dan $\mathrm{t}$ tabel $=1.9726$, maka $\mathrm{t}$ hitung $<\mathrm{t}$ tabel dengan nilai signifikansi $0.509>0.05$, sehingga variabel moderating tidak mempengaruhi hubungan variabel independen terhadap variabel dependen. Oleh karena itu dapat disimpulkan bahwa ukuran KAP sebagai variabel moderating memperlemah pengaruh opini audit terhadap harga saham. Dengan kata lainukuran KAP tidak berpengaruh hubungan opini audit dengan harga saham maka $\mathrm{H} 2$ ditolak.

\section{PENUTUP}

Penelitian ini menggunakan sampel sebanyak 63 perusahaan dengan dengan 189 observasi selama kurun waktu 2013-2015. Penelitian menggunakan pooled data untuk menjawab tiga hipotesis yang diajukan pada bab sebelumnya. Secara umum dapat disimpulkan bahwaOpini audit tidak berpengaruh signifikan terhadap harga saham pada perusahaan manufaktur yang terdaftar di Bursa Efek Indonesia.Keadaan tersebut menunjukkan bahwa opini audit tidak memiliki kandungan informasi, karena tidak memberikan pengaruh terhadap harga saham. Sedangkan ukuran kantor akuntan publik tidak dapat memoderasi hubungan opini audit dengan harga saham pada perusahaan manufaktur.Hasil penelitian ini memiliki implikasi bagi peneliti selanjutnya bahwa opini audit tidak berpengaruh signifikan terhadap harga saham. Penelitian selanjutnya dapat meneliti opini audit terhadap harga saham dengan menggunakan proksi yang berbeda, 
misalnya menggunakan data primer atau menjadikan likuiditas dan profitabilitas sebagai pemoderasi hubungan opini audit dengan harga saham.

Terdapat beberapa keterbatasan yang tak dapat dihindari oleh penulis selama proses penelitian ini. Keterbatasanini diduga berpengaruh terhadap hasil penelitian.Keterbatasan penelitian ini diantaranya tidak melihat faktor-faktor lain yang mungkin mempengaruhi harga saham.Penelitian ini juga tidak dilakukan terhadap sektor non manufaktur yang sebenarnya mungkin bisa memiliki pengaruh signifikan terhadap harga saham.Keterbatasan lain adalah sesuai dengan fenomena yang diungkap, penelitian ini hanya menggunakan perusahaanperusahaan yang terdaftar di BEI, oleh Karena itu hasil penelitian belum tentu dapat digeneralisasikan pada perusahaan-perusahaan non manufaktur terdaftar di BEI apalagi mungkin dari wilayah lain.

\section{DAFTAR PUSTAKA}

Agoes, Sukrisno.(2016).Auditing (Petunjuk Praktis Pemeriksaan Akuntan oleh Kantor Akuntan Publik).Cetakan Keempat.Jakarta : Salemba Empat

Almuntaha, Eska.,dkk.(2016).Apakah Reputasi Akuntan Publik Mempengaruhi Kestabilan Harga Saham.Simposium Nasional Akuntansi XIX, Lampung

Amperaningrum, Izzati., dan Agung, Suryawan, Robby.(2011).Pengaruh Tingkat Suku Bunga SBI, Nilai Tukar Mata Uang dan Tingkat Inflasi Terhadap Perubahan Harga Saham Sub Sektor Perbankan di BEI.Proceeding Psikologi, Ekonomi, Sastra, Arsitektur \& Sipil, Vol.4, Hal : 160-164

Anisma, Yuenita.(2012).Faktor-Faktor Yang Mempengaruhi Harga Saham Perusahaan Perbankan yang Listing di Bursa Efek Indonesia (BEI).Jurnal Sosial Ekonomi Pembangunan, Tahun II No. 5, hal : 144-165

Arinda, dan M.Syafruddin.(2013).Pengaruh Pengumuman Laporan Audit Wajar Tanpa Pengecualian Terhadap Harga Saham pada Perusahaan Jasa Keuangan dengan Kualitas Audit sebagai Variabel Moderating.Journal of Accounting Volume 2 No.4 hal: $1-10$

Ariningtika, Pradesta.(2013).Pengaruh Praktik Tata Kelola Perusahaan yang Baik Terhadap Pengungkapan Lingkungan Perusahaan.Skripsi

Barkemeyer, Ralf.(2007).Legitimacy as a Key Driver and Determinant of CSR in Developing Countries.Paper for 2007 Marie Curie Summer School on Earth System Governance, 28 May-06 June 2007, Amsterdam

Chrisnoventie, Diajeng.(2012).Pengaruh Ukuran KAP dan Spesialis Industri Terhadap Kualitas Audit : Tingkat Risiko Litigasi Perusahaan Sebagai Variabel Moderasi (Studi Empiris pada Perusahaan Manufaktur di BEI Tahun 2008-2010).Skripsi

Fadillah, Akbar.(2015).Pengaruh Opini Auditor Terhadap Pergerakan Harga Saham (Studi Kasus pada Perusahaan Pertambangan yang Terdaftar di BEI tahun 20112013).Diploma Thesis

Fahlevi, Reza, Ilham.(2013). Pengaruh Rasio Likuiditas, Profitabilitas dan Solvabilitas Terhadap Harga Saham (Studi Empiris pada Industri Perbankan yang Terdaftar Di Bursa Efek Indonesia Tahun 2008-2010).Skripsi

Fiatmoko, Latif, Arizal.(2015).Pengaruh Ukuran Perusahaan, Ukuran KAP, Laba/Rugi Operasi dan Opini Audit Terhadap Audit Delay pada Perusahaan Perbankan yang Terdaftar di BEI tahun 2010-2012.Skripsi

Ferdianto, Egi.(2014).Analisis Pengaruh Return On Assets (ROA), Debt To Equity Ratio (DER), Net Profit Margin (NPM), dan Current Ratio (CR) Terhadap Harga Saham 
(Studi Empiris Pada Perusahaan Tambang yang Terdaftar di BEI tahun 20112013).Skripsi

Ghozali, Imam.(2014).Ekonometrika (Teori, Konsep dan Aplikasi dengan IBM SPSS 22).Semarang : Badan Penerbit - Undip

Kabajeh, Majed Abd. Majid, et. al.,(2012).The Relationship between the ROA, ROE and ROI Ratios with Jordanian Insurance Public Companies Market Share Prices. International Journal of Humanities and Social Science, Vol. 2 No. 11. Page:115-120

Kipkosgei, Christhoper, Tanui.(2010).The Effect of Modified Audit Opinions on Share Prices for Companies Quoted at The Nairobi Stock Exchange.Skripsi

Laksitafresti, Astri.(2012).Pengaruh Opini Wajar Tanpa Pengecualian Dengan Paragraf Penjelas (WTP-PP) dan Opini Wajar Dengan Pengecualian (WDP) Terhadap Harga Saham dan Volume Perdagangan Saham (Studi Empiris Pada Perusahaan Manufaktur Yang Terdaftar Di Bursa Efek Indonesia (BEI) Pada Periode 2004-2010).Skripsi

Lin, Cecilia., and H.Wu, Frederick.(2009).The Information Contents of Modified Unqualified Audit Opinions Under the Control of Concurrent Information (The Case of Taiwan).Journal of Accounting and Corporate Governance, Volume 6 Number 1, pp.31-56

Mardiyatnolo, Aji.,dkk.(2016).Pengaruh Kepemilikan Manajerial, Kualitas Audit, dan Kinerja Keuangan terhadap Corporate Environmental Disclosure Sebagai Bentuk Tanggung Jawab Sosial Dalam Laporan Tahunan.Seminar Nasional dan The $3 d$ Call for Syariah Paper, ISSN 2460-0784, hal:220-227

Marindah, Afri.(2013).Pengaruh Audit Report Lag, Earnings Per Share, Opini Audit, dan Kantor Akuntan Publik Terhadap Harga Saham pada Perusahaan Manufaktur yang Terdaftar di BEI.Skripsi

Meythi, dkk.(2011). Pengaruh Likuiditas dan Profitabilitas Terhadap Harga Saham Perusahaan Manufaktur yang Terdaftar di Bursa Efek Indonesia.Jurnal Bisnis Manajemen dan Ekonomi, Volume 10, No. 2, hal. 2671-2684

M.Hanafi, Mamduh., dan Halim, Abduh.(2012).Analisis Laporan Keuangan.Edisi Keempat.Yogyakarta : Unit Penerbit dan Percetakan Sekolah Tinggi Ilmu Manajemen YKPN

Mulyadi.(2011).Auditing.Cetakan Kedelapan.Jakarta : Salemba Empat

O'donovon, Gary.(2002).Environmental Disclosures in the Annual Report: Extending the Applicability and Predictive Power of Legitimacy Theory.Accounting, Auditing \& Accountability Journal vol.15 Issue: 3, pp.344-371

Pardosi, Gerhat.(2012).Analisis Pengaruh Opini Auditor, Audit Report Lag dan Kantor Akuntan Publik Terhadap Harga Saham pada Perusahaan Manufaktur yang Terdaftar di Bursa Efek Indonesia Tahun 2008-2010.Skripsi

Prasetyo, Wahyu, Angga, dan Rini.(2014).Perbandingan Reaksi Pasar Sebelum dan Sesudah Pengumuman Opini Audit Unqualified.Jurnal MIX, Volume IV, No.3 hal : 410-418

Prastowo D, Dwi.(2014).Analisis Laporan Keuangan (Konsep dan Aplikasi).Edisi ketiga.Yogyakarta : Unit Penerbit dan Percetakan Sekolah Tinggi Ilmu Manajemen YKPN

Prihadi, Toto.(2011).Analisis Laporan Keuangan (Teori dan Aplikasi).Cetakan II.Jakarta Pusat : Penerbit PPM

Purbawati, Dinalestari.(2016).Pengaruh Opini Audit dan Luas Pengungkapan Sukarela Terhadap Perubahan Harga Saham.Jurnal Administrasi Bisnis Volume 5 No.1 hal : 612 
Putri, Wahyu, Berty.(2012).Penentuan Kualitas Audit Berdasarkan Ukuran KAP dan Biaya Audit.Jurnal Ilmiah Mahasiswa Akuntansi Vol. 1 No.4 Hal : 60-64

Ratri, Destia, Teska.(2015). Pengaruh Kinerja Keuangan Terhadap Harga Saham Perusahaan Tekstil dan Produk Tekstil (TPT) yang Terdaftar di BEI Tahun 2009-2014.Skripsi

Santoso, Singgih.(2015).Menguasai SPSS 22 (From Basic to Expert Skill).Jakarta : PT. Elex Media Komputindo

Sarwono, Oon.(2016).Pengaruh Likuiditas dan Profitabilitas terhadap Harga Saham pada Perusahaan Manufaktur.Skripsi

Setiyawan, Indra.(2014).Pengaruh Current ratio, Inventory Turnover, Time Interest Earned da Return On Equity Terhadap Harga Saham Pada Perusahaan Manufaktur Sektor Barang Konsumsi yang Terdaftar di BEI.Jurnal Nominal volume III No.2 hal : 117133

Sidabutar, Silvia, Mega.(2014).Pengaruh Opini Audit, Audit Report Lag, dan Ukuran KAP Terhadap Harga Saham Pada Perusahaan Manufaktur yang Terdaftar di BEI Tahun 2010-2012.Skripsi Program Studi Akuntansi

Sugiyono.(2015).Metode Penelitian Kuantitatif, Kualitatif, dan R\&D.Cetakan Ke22.Bandung : Alfabeta

Susila, Budi, Agung.(2015).Pengaruh Opini Auditor Terhadap Harga Saham.Skripsi

Sutanto, Sandre.(2007).Faktor-Faktor yang Mempengaruhi Harga Saham di Bursa Efek Jakarta.Skripsi

Tyas, Aning, Rizqi., dan Saputra, Septa, Rishi.(2016). Analisis Pengaruh Profitabilitas Terhadap Harga Saham (Studi Kasus Perusahaan Telekomunikasi Yang Terdaftar di Bursa Efek Indonesia (BEI) Periode 2012-2014). JURNAL ONLINE INSAN AKUNTAN, Vol.1, No.1, hal : 77 - 91 E-ISSN: 2528-0163

Wiasta, Widi, Janu.(2010).Analisis Pengaruh Profitabilitas Terhadap Harga Saham pada Lembaga Keuangan yang Go Public di BEI. Jurnal Online INSAN AKUNTAN, Vol.1, No.1, hal : $77-91$

Wicaksono, Adhitya, Hendra.(2013). Pengaruh Current Ratio, Debt to Assets Ratio, Total Assets Turnover, Return On Equity, Suku Bunga, Kurs Valuta Asing, Inflasi, dan KasDividen Terhadap Harga Saham Perusahaan Makanan dan Minuman yang Terdaftar di BEI periode 2009-2011.Skripsi

Zhao, J., A. L. Katchova, dan P. J. Barry. (2004). Testing the Pecking Order Theory and the Signaling Theory for Farm Businesses. American Agricultural Economics Association Annual Meeting. Denver, Colorado. July: 1-4.

www.idx.co.id 